\title{
Optimis, Pesimis, atau Realistis: Kajian Terhadap Perspektif Qoheleth Mengenai Kehidupan
}

\author{
Phillips Steven, ${ }^{1 *}$ David Alinurdin ${ }^{2}$ \\ 1,2 Sekolah Tinggi Teologi SAAT \\ *philips.steven17@seabs.ac.id
}

\section{DOI: https://doi.org/10.34307/ b.v4i1.230}

\begin{abstract}
The book of Ecclesiastes shows Qoheleth's viewpoints that seem contradictory. On the one hand, Qoheleth looks like a pessimistic nihilist about life under the sun, which is judged in vain because everything leads to death. However, on the other hand, Qoheleth also looks optimistic with his advice to enjoy pleasure through eating, drinking, and joyful living. Therefore, it is not surprising that Qoheleth was once considered a neurotic who doubted himself. However, recent studies show that Qoheleth deliberately uses contradictions as complex irony to invite readers to look at the realities of life and reflect on that life is meaningful because of its purpose, significance, and coherence. By referring to the view that Qoheleth is teaching the meaning of life, this paper aims to show Qoheleth's perspective on life that is not pessimistic or optimistic but realistic. By using the method of in-textuality, inner-textuality, and inter-textuality analysis, it is concluded that Qoheleth views that although death is inevitable, it should not be treated with pessimism but by fearing God, carrying out His commands, and enjoying His blessings like Adam. and Eve in the garden of Eden, because God will bring every human act to the final judgment and there is life after death.
\end{abstract}

Keywords: Qoheleth, in-textuality, inner-textuality, inter-textuality

Abstrak: Kitab Pengkhotbah memperlihatkan cara pandang Qoheleth yang tampak kontradiktif. Di satu sisi Qoheleth terlihat seperti seorang nihilis yang pesimistis terhadap kehidupan di bawah matahari, yang dinilainya sia-sia karena semua berujung pada kematian. Namun di sisi lain, Qoheleth juga terlihat optimis dengan nasihatnya untuk menikmati kesenangan melalui makan, minum dan bersukaria. Oleh sebab itu, tidaklah mengherankan jika Qoheleth pernah dianggap seorang neurotik yang meragukan dirinya sendiri. Namun demikian, studi terkini menunjukkan bahwa Qoheleth sengaja menggunakan kontradiksi sebagai ironi kompleks untuk mengajak pembacanya melihat realitas kehidupan dan merenungkan bahwa hidup itu bermakna karena ada tujuan, signifikansi dan koherensinya. Dengan mengacu kepada pandangan bahwa Qoheleth sedang mengajarkan makna kehidupan maka tulisan ini bertujuan untuk memperlihatkan perspektif Qoheleth mengenai kehidupan yang bukan pesimis atau optimis, melainkan realistis. Dengan menggunakan metode analisis in-textuality, innertextuality dan inter-textuality dihasilkan kesimpulan bahwa Qoheleth memandang meskipun kematian tidak terhindarkan, tidak semestinya disikapi dengan pesimistis melainkan dengan takut akan Tuhan, melakukan perintah-perintah-Nya, dan menikmati berkat-Nya seperti Adam dan Hawa di taman Eden, karena Allah akan membawa setiap perbuatan manusia ke pengadilan akhir dan ada kehidupan sesudah kematian.

Kata kunci: Kitab Pengkhotbah, in-textuality, inner-textuality, inter-textuality 


\begin{tabular}{llll}
\hline Article History & Received: 09-02-2021 & Revised: 22-05-2021 & Accepted: 02-06-2021 \\
\hline
\end{tabular}

\section{Pendahuluan}

Pandemi COVID-19 yang melanda seluruh dunia di tahun 2020 membuat banyak orang khawatir. Aktivitas yang biasa dilakukan secara normal, kini harus mendapat banyak penyesuaian. Himbauan pemerintah agar masyarakat berada di rumah saja, dan melakukan aktivitas seperti belajar, bekerja, maupun beribadah dari rumah, semata-mata adalah untuk memutus rantai penyebaran virus corona. Bertambahnya angka kematian akibat infeksi virus ini setiap harinya terus bertambah secara eksponensial. ${ }^{1}$ Tidak dapat dipungkiri bahwa situasi seperti ini membuat banyak orang mulai memikirkan tentang kehidupan. Apa arti kehidupan ini kalau pada akhirnya harus menghadapi kematian? Bukankah kematian akan mengeliminasi semua pencapaian yang telah diperoleh selama hidup di dunia? Pertanyaan-pertanyaan seputar kehidupan dan kematian ini juga ditanyakan oleh Qoheleth ${ }^{2}$ di dalam kitab Pengkhotbah. Qoheleth digambarkan seperti seorang pengamat yang melihat semua hal yang terjadi dalam kehidupan "di bawah matahari" dan memberikan penilaian terhadapnya.

Seringkali yang menjadi perdebatan dalam memahami kitab Pengkhotbah adalah bagaimana sebenarnya perspektif Qoheleth tentang kehidupan ini, apakah pesimis ataukah optimis. Jika dilihat secara sekilas, tampaknya kitab ini memang bernuansa pesimis, sebab diawali dengan kata "kesia-siaan belaka" (1:2), dan diakhiri juga dengan kata "kesia-siaan belaka" (12:8). Namun, di sisi lain, Qoheleth juga terlihat seperti optimis terhadap hidup ini ketika mengajak pembacanya untuk menikmati kesenangan di dalam hidup mereka, seperti makan, minum dan bersukaria $(2: 24-26$; 3:12-13, 22; 5:17-19; 8:15; 9:7-10; 11:7-10). Para sarjana biblika pun terbagi dalam memahami perspektif Qoheleth. Mark R. Sneed memandang Qoheleth sebagai seorang skeptis dan pesimis. ${ }^{3}$ Sebaliknya, Eunny P. Lee melihat Qoheleth sebagai seorang optimis dengan pandangan teologis sukacita dan kesenangan hidup (enjoyment) demi berkembangnya kehidupan manusia secara melimpah (flourishing) di dunia ini. ${ }^{4}$ Senada dengan Lee, T. A. Perry juga berargumen bahwa fokus kitab Pengkhotbah adalah hidup yang menyenangkan (joyous living). ${ }^{5}$

\footnotetext{
${ }^{1}$ Menurut data peta sebaran dari Satuan Tugas Penangangan COVID-19 Indonesia, dari sejak Maret 2020 hingga 21 Mei 2021, total ada 1.758 .898 kasus terkonfirmasi dengan 88.439 kasus aktif, dan 48.887 orang yang meninggal. Lihat dalam https://covid19.go.id/peta-sebaran, diakses 21 Mei 2021.

${ }^{2}$ Sepanjang artikel ini, penulis akan menggunakan istilah "Pengkhotbah" untuk kitab Pengkhotbah, dan istilah "Qoheleth" untuk sang Pengkhotbah.

${ }^{3}$ Mark R. Sneed, The Politics of Pessimism In Ecclesiastes: A Social-Science Approach (Atlanta: Society of Biblical Literature, 2012), 4-9.

${ }^{4}$ Eunny P. Lee, The Vitality of Enjoyment in Qohelet's Theological Rhetoric (Berlin: Walter de Gruyter, 2005), 124-139.

5T. A. Perry, The Book of Ecclesiastes (Qohelet) and the Path to Joyous Living (Cambridge: Cambridge University Press, 2015), 11.
} 
Meskipun kitab Pengkhotbah sering kali dijuluki sebagai kitab kontradiksi, ${ }^{6}$ para sarjana melihat kontradiksi tersebut sebagai sebuah ironi kompleks yang memang sengaja digunakan Qoheleth untuk mengajak pembacanya melihat realitas kehidupan dan merenungkan maknanya. ${ }^{7}$ Beberapa penelitian terakhir mengenai kitab Pengkhotbah memperlihatkan bahwa Qoheleth memang sedang memperlihatkan bahwa hidup itu bermakna, ada tujuan, signifikansi dan koherensinya. ${ }^{8}$ Lebih dari itu, Jesse M. Peterson mengatakan bahwa Qoheleth bukan seorang nihilis yang pesimistis, juga bukan seorang optimis yang naif, melainkan seorang realis yang moderat. ${ }^{9}$ Dengan memperhatikan perdebatan mengenai kontradiksi yang ada di dalam kitab Pengkhotbah dan bagaimana pandangan Qoheleth mengenai makna kehidupan, maka artikel ini ditulis dengan tujuan untuk memperlihatkan bahwa perspektif Qoheleth tentang kehidupan bukanlah pesimistis ataupun optimistis, melainkan realistis.

\section{Metode Penelitian}

Metode yang digunakan penulis adalah eksegesis menggunakan tiga analisis yaitu intextuality, inner-textuality, dan inter-textuality. ${ }^{10}$ Analisis in-textuality merupakan analisis yang berfokus pada sebuah perikop teks tertentu dengan berbagai metode kritis, dalam hal ini penulis menggunakan kritik teks. ${ }^{11}$ Tetapi, kritik teks yang digunakan tidak berhenti pada dirinya sendiri, melainkan untuk mendapatkan terjemahan serta penafsiran yang lebih tepat. Lalu, analisis inner-textuality merupakan analisis yang berfokus pada bagian yang lebih besar dari perikop teks tertentu, dalam hal ini penulis berfokus pada kitab di mana teks itu berada, yaitu kitab Pengkhotbah. ${ }^{2}$ Tujuan dari analisis ini adalah untuk mendapatkan gambaran yang lebih besar serta keterkaitan teks dengan kitab (mis. latar belakang kitab, nuansa dalam kitab, dll.). Berikutnya, analisis inter-textuality merupakan analisis yang berfokus pada keterkaitan satu kitab dengan kitab lainnya, baik itu dalam perjanjian yang sama (PL-PL atau PB-PB), maupun antar

\footnotetext{
${ }^{6}$ Lee, The Vitality of Enjoyment, 1.

${ }^{7}$ Misalnya James L. Crenshaw, Qoheleth: The Ironic Wink (Columbia: University of South Carolina Press, 2013), 7-8.

${ }^{8}$ Arthur Keefer, "The Meaning of Life in Ecclesiastes: Coherence, Purpose, and Significance from a Psychological Perspective," Harvard Theological Review 112, no. 4 (2019): 447-466, https://doi.org/10.1017/S0017816019000233.

${ }^{9}$ Jesse M. Peterson, "Is Coming into Existence Always a Harm? Qoheleth in Dialogue with David Benatar," Harvard Theological Review 112, no. 1 (2019): 53, https://doi.org/10.1017/S0017816018000330.

${ }^{10}$ Penulis menggunakan ketiga analisis tersebut dengan asumsi bahwa setiap teks memiliki kesatuan yang saling berhubungan. Penjelasan lebih lanjut mengenai ketiga analisis ini dapat dilihat dalam John H. Sailhamer, Introduction to Old Testament Theology: A Canonical Approach (Grand Rapids: Zondervan, 2010), 197-252.

11Ibid., 208.

12Ibid., 209-212.
} 
perjanjian yang berbeda (PL-PB). Keterkaitan dengan Kristus, sebagai penggenapan PL juga termasuk ke dalam analisis ini. ${ }^{13}$

Pada bagian yang pertama, analisis in-textuality akan difokuskan pada teks Pengkhotbah 12:1-7. Perikop tersebut dipilih karena dianggap sebagai karya monumental (masterpiece) dari Qoheleth dan juga sekaligus bagian yang paling kontroversial dalam kitab Pengkhotbah. ${ }^{14}$ Perikop ini menjelaskan tentang masa penuaan yang berujung kepada kematian, yaitu suatu momen yang meniadakan seluruh pencapaian yang telah diperoleh selama seseorang hidup. Di dalam analisis ini, penulis akan memaparkan problem teks yang ada demi mendapatkan terjemahan teks yang tepat, dan kemudian struktur perikop untuk memperlihatkan kata kunci dan penekanan yang ingin disampaikan Qoheleth. Semua analisis tersebut dilakukan untuk memberikan penafsiran yang tepat mengenai pesan yang ingin disampaikan Qoheleth dalam perikop tersebut.

Pada bagian yang kedua, analisis inner-textuality akan menganalisis kitab Pengkhotbah itu sendiri, dimulai dengan latar belakang kitab tersebut secara historis, dan dilanjutkan dengan struktur, genre, dan nuansa kitab. Selain itu, juga akan dibahas tentang konsep-konsep yang berhubungan dengan kehidupan maupun kematian dalam kitab ini.

Pada bagian yang terakhir, penulis akan melakukan analisis inter-textuality untuk melihat bahwa konsep-konsep teologis dalam kitab Pengkhotbah itu berhubungan erat dengan konsep-konsep pada teks kitab-kitab lain. Hal ini dilakukan untuk membuktikan bahwa apa yang menjadi pemahaman Qoheleth tentang kehidupan sebenarnya sejalan dengan apa yang teks-teks lain katakan. Teks-teks yang dimaksud di antaranya adalah teks dalam kitab Ayub dan Amsal sebagai sesama literatur hikmat dan teks dalam kitab Kejadian (karena berhubungan dengan permulaan kehidupan). Selain itu, penulis juga akan secara khusus menghubungkannya dengan Kristus, yang merupakan Sang Pemberi hidup.

\section{Hasil dan Pembahasan}

\section{Analisis In-Textuality Pengkhotbah 12:1-7}

\section{Problem Tekstual dalam Pengkhotbah 12:1-7}

Beberapa bagian dalam teks Pengkhotbah 12:1-7 memiliki problem. Problem-problem yang muncul adalah berkaitan dengan morfologi dan gramatikal bahasa Ibraninya, ketidaksesuaian dengan konteks, serta perbedaan yang muncul dalam manuskripmanuskrip. Dengan mempertimbangkan banyak hal, para ahli pun mengoreksi kesalahankesalahan tersebut. Koreksi tersebut menimbulkan banyak perdebatan. Oleh karena itu

13Ibid., 212-213.

${ }^{14}$ Hans Debel, "When It All Falls Apart: A Survey of the Interpretational Maze Concerning the 'Final Poem' of the Book of Qohelet (Qoh. 12:1-7)," Old Testament Essays 23, no. 2 (2010): 235-236. 
dalam bagian ini, penulis akan memaparkan problem yang ada dan koreksi yang telah dibuat oleh para ahli. Di akhir bagian ini, penulis akan memberikan terjemahan teks Pengkhotbah 12:1-7 yang lebih tepat berdasarkan pertimbangan-pertimbangan yang ada.

Pertama, problem muncul pada kata memakai akhiran maskulin bentuk jamak, sehingga seharusnya jika diartikan secara literal menjadi "Pencipta-penciptamu". Tetapi, secara konteks, tampaknya terjemahan dari kata tersebut kurang tepat. Jika dilihat dalam konteks keseluruhan pasal 12, peristiwa yang sedang digambarkan adalah peristiwa penuaan dan berujung kepada kematian. Oleh karena itu, R. B. Y. Scott menawarkan untuk mengganti terjemahan kata

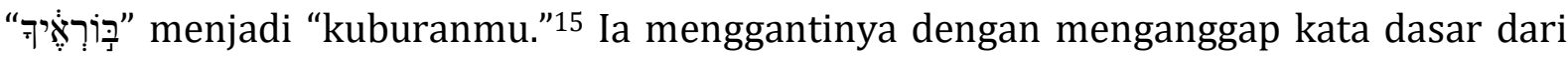
בִּר (cistern, well, grave) ${ }^{16}$ dan bukan ditambahkan akhiran menjadi §ִרּ (your grave). Dengan demikian, persoalan bentuk jamak yang dikenakan kepada Allah selesai ketika menggantinya dengan kata "kuburanmu." Lagipula sepanjang kitab Pengkhotbah, Qoheleth selalu menyebut yang ilahi dengan sebutan אֶלה (Allah), dan tidak ada kata ganti khusus untuk kata "Allah."18

Kedua, kata וְרזה (the light) di ayat 2 tampaknya merusak susunan tiga jenis benda penerang yang dicatat dalam Kejadian 1:16, yaitu matahari, bulan, dan bintang-bintang.

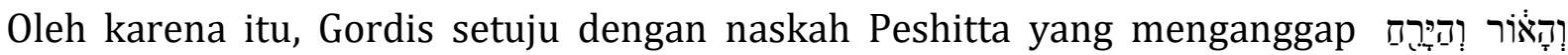
ודהּכּוֹכָיָים (the light, the moon, and the stars) sebagai hendiadys ${ }^{19}$, sehingga terjemahan yang lebih tepat adalah "and the light of the moon and the stars." 20

Ketiga, pada ayat ke-5 terdapat perbedaan antara kata ירָ': (they fear) yang ditulis dalam MT dengan kata רִיר (they see) yang ditulis dalam beberapa manuskrip seperti G,

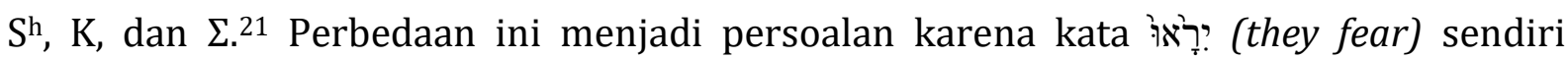
memiliki kata dasar ירירא (to fear) sehingga apabila ditambahkan awalan ? dan akhiran

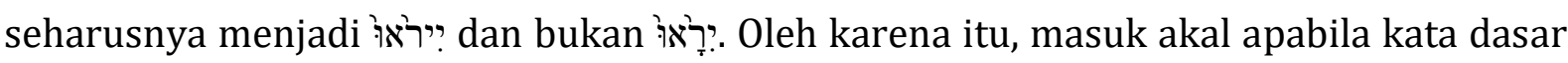
dari kata tersebut adalah רָאָה (to see) supaya ketika ditambahkan awalan? dan akhiran ? menjadi יִרִאר. Walaupun demikian, penulisan defective $e^{22}$ juga dimungkinkan dalam hal ini,

15R. B. Y. Scott, Proverbs, Ecclesiastes, ed. ke-2, The Anchor Bible 18 (New York: Doubleday, 1985), 255.

16Willem A. VanGemeren, ed., New International Dictionary of Old Testament Theology \& Exegesis, vol. 1 (Grand Rapids: Zondervan, 1997), 620.

17Ibid., 1:728.

${ }^{18}$ Scott, Proverbs, Ecclesiastes, 255.

${ }^{19}$ Hendiadys adalah cara untuk menyusun satu ide dengan membaginya menjadi dua bagian atau lebih. Sebagai contoh: "the light, the moon, and the stars" sebenarnya merujuk kepada satu ide, yaitu: "the light of the moon and the stars", tetapi karena memakai bentuk hendiadys, kalimat tersebut dibagi menjadi tiga bagian.

${ }^{20}$ Robert Gordis, Koheleth - The Man and His World: A Study of Ecclesiastes, ed. ke-3 (New York: Schocken Books, 1968), 341.

${ }^{21} \mathrm{G}$ : LXX, Sh: Syro-Hexaplar, K: Coptic, $\Sigma$ : Symmachus.

${ }^{22}$ Penulisan defective adalah penulisan kata Ibrani yang lebih pendek (disingkat). 
sehingga meskipun setelah ditambahkan awalan ? dan akhiran 3, kata yang berubah

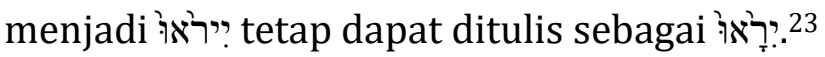

Persoalan lainnya dari kata ירָאר יראיר: (they fear) adalah berkaitan dengan subjeknya. Subjek kata tersebut adalah orang ketiga jamak, sedangkan dari konteks dekat ayat tersebut subjeknya adalah orang ketiga tunggal. Hal ini dapat diketahui dari kata ויזיקוּל yang memakai bentuk tunggal. Perubahan subjek kata ירָאר : dari bentuk tunggal ke jamak disebabkan oleh dittografi, yaitu penambahan ; di akhir kata tersebut. Meskipun demikian, Anton Schoors berpendapat bahwa hal itu tidak menjadi masalah, karena dengan memakai subjek bentuk jamak, kata tersebut dapat ditujukan kepada subjek yang lebih luas. ${ }^{24}$

Persoalan lainnya dari kata ?רָאוּ (they fear) adalah berkaitan dengan subjeknya. Subjek kata tersebut adalah orang ketiga jamak, sedangkan dari konteks dekat ayat tersebut subjeknya adalah orang ketiga tunggal. Hal ini dapat diketahui dari kata יִיקוּל

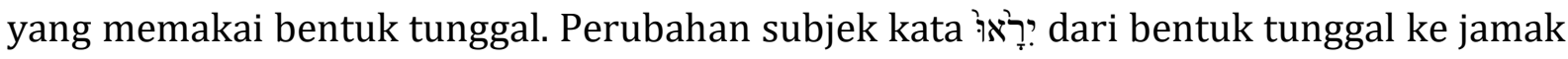
disebabkan oleh dittografi, yaitu penambahan ; di akhir kata tersebut. Meskipun demikian, Anton Schoors berpendapat bahwa hal itu tidak menjadi masalah, karena dengan memakai subjek bentuk jamak, kata tersebut dapat ditujukan kepada subjek yang lebih luas. ${ }^{25}$

Keempat, kata וٕיניגא pada ayat 5 juga perlu mendapat perhatian. Banyak terjemahan mengartikan kata tersebut sebagai "blossoms." Padahal apabila diperhatikan dengan lebih

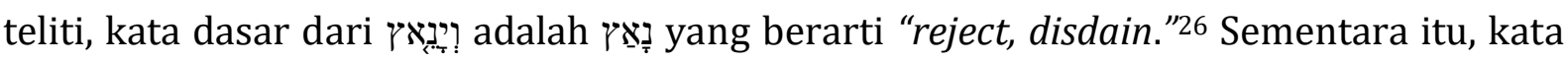
dasar untuk "blossoms" dalam bahasa Ibrani adalah נצ. ${ }^{27}$ Setelah melakukan penyelidikan lebih lanjut, ternyata para penafsir atau penerjemah menerjemahkannya sebagai

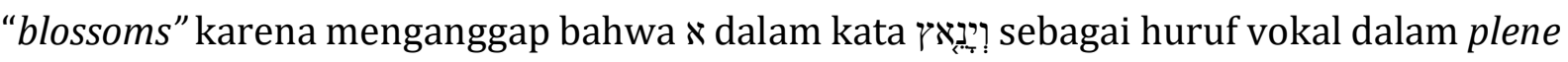

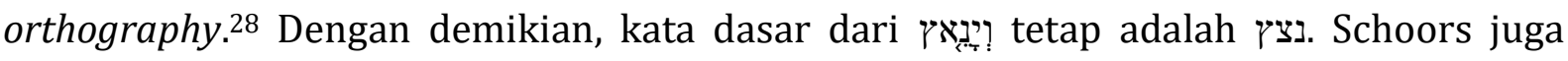

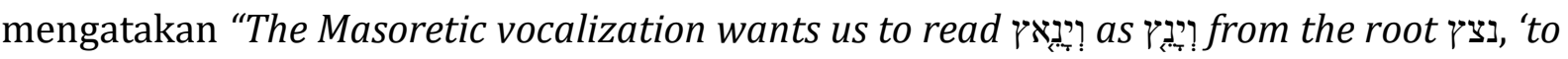
blossom'."29 Jadi, secara tidak langsung sebenarnya ada kemungkinan para penyalin teks tersebut melakukan kesalahan, yaitu ketika menambahkan $x$ yang seharusnya tidak diperlukan.

Kelima, pada ayat 5 juga muncul frasa (eternal home). Bukti-bukti ekstrabiblika, seperti Palymrene inscription dari abad 2 SM, Punic inscription, penggunaan

\footnotetext{
${ }^{23}$ Charles F. Whitley, Koheleth: His Language and Thought (New York: Walter de Gruyter, 1979), 97.

${ }^{24}$ Anton Schoors, The Preacher Sought to Find Pleasing Words: A Study of the Language of Qoheleth, Orientalia Lovaniensia Analecta 41 (Leuven: Peeters Press, 1992), 28.

${ }^{25}$ Anton Schoors, The Preacher Sought to Find Pleasing Words: A Study of the Language of Qoheleth, Orientalia Lovaniensia Analecta 41 (Leuven: Peeters Press, 1992), 28.

${ }^{26}$ Willem A. VanGemeren, ed., New International Dictionary of Old Testament Theology \& Exegesis, vol. 3 (Grand Rapids: Zondervan, 1997), 5.

${ }^{27}$ Ibid., 3:147.

${ }^{28}$ Whitley, Koheleth, 98 . Plene orthography adalah bentuk penulisan yang lebih panjang (lawan dari defective writing).

${ }^{29}$ Schoors, The Preacher Sought to Find Pleasing Words, 42.
} 
kata-kata tersebut di Mesir, Targum Yesaya 14:18, dan lain-lain menunjukkan bahwa frasa tersebut merujuk kepada kuburan. ${ }^{30}$ Tetapi, Ronald F. Youngblood menawarkan pengertian yang lain. "I am proposing that 'dark house' is a better contextual translation of in Ecclesiastes 12:5 than is 'eternal home' or the equivalent."31 Ia mengatakan bahwa dari delapan kemunculan עi dalam kitab Pengkhotbah, lima di antaranya diawali dengan awalan ? $(1: 4 ; 1: 10 ; 2: 16 ; 3: 14 ; 9: 6)$ dan memiliki arti "for a long time" atau "forever." Yang keenam adalah (12:14) yang berarti "hidden thing." Dua lainnya terletak pada 3:11 dan 12:5.

Pada Pengkhotbah 3:11, kata דָעזלָם seringkali diterjemahkan sebagai "eternity." Tetapi, dengan terjemahan tersebut tampaknya menjadi kurang cocok dengan kalimat setelahnya. Bagaimana mungkin Allah memberikan "eternity" pada manusia, tetapi manusia tidak dapat menyelami pekerjaan Allah dari awal sampai akhir? Kalimat tersebut menjadi tidak terlalu cocok. Hal inilah juga yang dikatakan oleh George A. Barton, "To say that 'God has put eternity in their heart, so that they cannot find out the work of God from beginning to end,' makes no sense ... From this same root y. frequently used in the Talmud...., means 'that which is 'concealed,' 'secret,' etc."32 Jadi, kalimat dalam Pengkhotbah

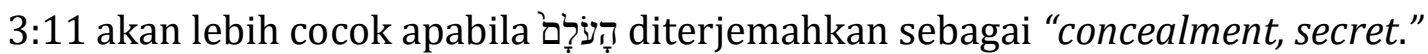

Selain itu, kata הָעזָר sendiri memiliki hubungan dengan bahasa Ugaritik ('glm), dan bahasa Arab (z lm), yang berarti "to be dark." ${ }^{33}$ Dengan demikian, pada Pengkhotbah 12:5,

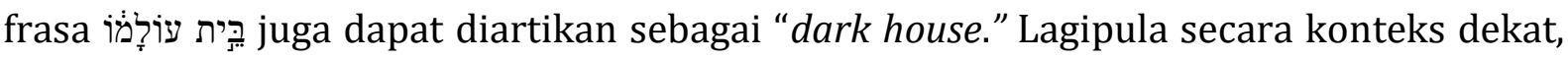
gambaran situasi yang diberikan oleh Qoheleth adalah tentang penuaan dan menuju kepada sesuatu yang gelap, yaitu kematian. Jadi, justru terjemahan "dark house" akan

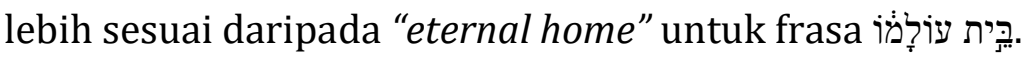

Ketujuh, pada ayat 6 kata "is broken" (NASB) memiliki dua versi, yaitu yang tercatat pada Qere (Q) dan Kethibh (K). ${ }^{34}$ Q mencatat kata ר.? kata ירחק (be distant, be far). Pada ayat 6, kata itu merupakan bentuk niphal privative dari kata רָת (chain). ${ }^{35}$ Jika menggunakan catatan K, kata ירוֹקק tidak pernah dicatat di bagian manapun dalam Alkitab dengan menggunakan bentuk niphal. Jadi, pembacaan terhadap

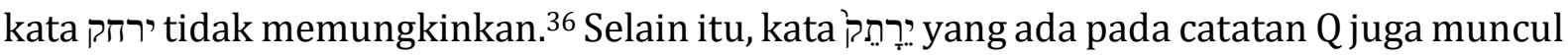
sebanyak dua kali, yaitu pada Pengkhotbah 12:6 dan di Nahum 3:10. Di sisi lain, Paul

\footnotetext{
${ }^{30}$ Tremper Longman III, The Book of Ecclesiastes, The New International Commentary on the Old Testament (Grand Rapids: Wm. B. Eerdmans Publishing Co., 1998), 266.

${ }^{31}$ Ronald F. Youngblood, "Qoheleth's 'Dark House' (Eccl. 12:5)," Journal of the Evangelical Theological Society 29, no. 4 (Desember 1986): 401.

${ }^{32}$ George A. Barton, A Critical and Exegetical Commentary on the Book of Ecclesiastes, The International Critical Commentary 17 (New York: Scribner, 1908), 105.

${ }^{33}$ VanGemeren, New International Dictionary of Old Testament Theology \& Exegesis, 3:425.

${ }^{34}$ Pembacaan Masoretic atau pengucapannya disebut sebagai Qere (Aramaic קרי "to be read"), sedangkan ejaan konsonan sebelum Masoretic disebut sebagai Kethibh (Aramaic כתיב "what is").

${ }^{35}$ Gordis, Koheleth - The Man and His World, 347.

${ }^{36}$ Schoors, The Preacher Sought to Find Pleasing Words, 39.
} 
Joüon mengatakan bahwa Qere sering kali (walaupun tidak selalu) memberikan pembacaan yang lebih superior. ${ }^{37}$ Dengan demikian, pembacaan yang paling kuat buktinya adalah pada catatan $\mathrm{Q}$, yang mencatat kata רִירתק dengan menggunakan bentuk niphal privative, yaitu menjadi "be severed."

Demikianlah pemaparan bagian-bagian teks dari Pengkhotbah 12:1-7 yang memiliki problem. Dengan pertimbangan-pertimbangan di atas, penulis akan menuliskan kembali terjemahan teks yang lebih tepat. Dalam terjemahan penulis, sebagian besar sesuai dengan terjemahan LAI-TB. Namun, ada terjemahan dua kata dalam teks yang penulis ubah, yaitu pada kata "penciptamu" menjadi "kuburanmu" dan kata "rumahnya yang kekal" menjadi "rumahnya yang gelap." Penulis setuju dengan perubahan terjemahan dua kata tersebut karena lebih cocok dengan konteks dekat teks tersebut, yaitu dari ayat 1 sampai 7. Qoheleth sedang berbicara tentang masa penuaan, dan berujung kepada kematian. Sebenarnya Qoheleth tidak bermaksud sama sekali untuk mengingatkan pembaca kepada Sang Pencipta karena menurutnya hal itu tidak akan mengubah apa-apa. Kematian adalah akhir dari segalanya. Dengan konsep Qoheleth yang seperti itu juga, maka terjemahan "rumahnya yang kekal" menjadi kurang sesuai karena jelas terlihat bahwa ia menganggap destinasi akhir dari hidup manusia adalah kematian. Bagi Qoheleth, hidup ini adalah kesia-siaan $(1: 2 ; 12: 8)$. Berikut terjemahan teks Alkitab menurut penulis:

1'Ingatlah juga akan kuburanmu pada masa mudamu, sebelum tiba hari-hari yang malang
dan mendekat tahun-tahun yang kau katakan: "Tak ada kesenangan bagiku di dalamnya!",
${ }^{2}$ sebelum cahaya dari matahari, bulan, dan bintang-bintang menjadi gelap, dan awan-
awan datang kembali sesudah hujan, ${ }^{3}$ pada waktu penjaga-penjaga rumah gemetar, dan
orang-orang kuat membungkuk, dan penggiling-penggiling berhenti karena berkurang
jumlahnya, dan yang melihat dari jendela semuanya menjadi kabur, ${ }^{4}$ dan pintu-pintu di
tepi jalan tertutup, dan bunyi penggilingan menjadi lemah, dan suara menjadi seperti
kicauan burung, dan semua penyanyi perempuan tunduk, 5juga orang menjadi takut
tinggi, dan ketakutan ada di jalan, pohon badam berbunga, belalang menyeret dirinya
dengan susah payah dan nafsu makan tak dapat dibangkitkan lagi - karena manusia pergi
ke rumahnya yang gelap dan peratap-peratap berkeliaran di jalan, ${ }^{6}$ sebelum rantai perak
diputuskan dan pelita emas dipecahkan, sebelum tempayan dihancurkan dekat mata air
dan roda timba dirusakkan di atas sumur, ${ }^{7}$ dan debu kembali menjadi tanah seperti
semula dan roh kembali kepada Allah yang mengaruniakannya.

\section{Struktur Teks Pengkhotbah 12:1-7}

Fox membagi Pengkhotbah 12:1-7 menjadi tiga bagian berdasarkan kemunculan frasa: אָשֶׁר לה (while before not). Berikut pembagiannya: ${ }^{38}$
(A) $\quad 12: 1 b$
Proses menuju kematian, pertama menua kemudian disusul dengan terhentinya kehidupan.
(B) 12:2-5 Reaksi terhadap kematian: penguburan.

\footnotetext{
${ }^{37}$ Seperti yang dikutip oleh Schoors (ibid., 33).

${ }^{38}$ Michael V. Fox, Qohelet and His Contradictions, Journal for the Study of the Old Testament Supplement Series 71 (Sheffield: Almond Press, 1989), 300.
} 
(C) 12:6-7 Proses menuju kematian, sugesti dari penguburan.

Melalui pembagian ini, maka kata imperatif וּזְר (and remember) yang terdapat pada 12:1, ditujukan kepada ketiga bagian tersebut.

\section{Penafsiran Teks Pengkhotbah 12:1-7}

Pengkhotbah 12:1-7 dapat ditafsirkan melalui tiga pendekatan, yaitu: literal, metaforis, dan alegoris. ${ }^{39}$ Penulis akan mengacu kepada penafsiran tradisional ${ }^{40}$ yang menggunakan pendekatan alegoris. ${ }^{41}$ Pendekatan alegoris ini mengartikan ayat 2 sampai 6 dengan mengacu kepada pelemahan organ-organ tubuh manusia.

Pada ayat 2, "matahari" merujuk kepada cahaya yang ada pada wajah, "cahaya" merujuk kepada mata, "bulan" merujuk kepada "dagu", "bintang-bintang" merujuk kepada kedua bola mata, "awan datang kembali sesudah hujan" merujuk kepada gelapnya wajah setelah menangis. ${ }^{42}$ Selanjutnya, pada ayat 3 terdapat pola A-B-A'-B' (laki-laki kelas bawah - laki-laki kelas atas - perempuan kelas bawah - perempuan kelas atas). ${ }^{43}$ Frasa "penjaga-penjaga rumah gemetar" merujuk pada tangan atau lutut yang gemetar, "orangorang kuat membungkuk" merujuk pada tubuh yang membungkuk, "penggilingpenggiling berhenti" merujuk pada gigi yang melemah dalam mengunyah makanan, dan "yang melihat dari jendela semuanya menjadi kabur" merujuk pada kedua bola mata yang mulai kabur.

Berikutnya, pada ayat 4, frasa "pintu-pintu di tepi jalan tertutup" merujuk kepada ketidakmampuan organ-organ tubuh bekerja. ${ }^{44}$ Selain itu, karena frasa tersebut memiliki bentuk dual, dapat juga diartikan sebagai bibir atas yang jatuh ke bawah. Frasa "bunyi penggilingan menjadi lemah" merujuk kepada pendengaran yang melemah, "suara

\footnotetext{
${ }^{39}$ Longman III, The Book of Ecclesiastes, 263.

${ }^{40}$ Etan B. Levine, The Aramaic Version of Qohelet (New York: Sepher-Hermon Press, 1978), 46-47.

${ }^{41}$ Di samping itu, literatur Timur Dekat Kuno, sebagai contoh "the Sumerian poet" juga menuliskan
} sajak yang serupa tentang masa tua dan harus ditafsirkan secara alegoris. Berikut sajaknya:

My grain roasting fails

Now my youthful vigor, strength and personal god

have left my loins like an exhausted ass.

My black mountain has produced white gypsum.

My mother has brought in a man from the forest; he gave me captivity.

My mongoose which used to eat strong smelling things does not stretch its neck towards beer and butter.

My urine used to flow in a strong torrent but now you flee from my wind.

My child whom I used to feed with butter and milk, I can no more support it.

And I have had to sell my little slave girl;

an evil demon makes me sick.

${ }^{42}$ Gordis, Koheleth - The Man and His World, 341.

${ }^{43}$ Longman III, The Book of Ecclesiastes, 270.

${ }^{44}$ Ibid., 271. 
menjadi seperti kicauan burung” merujuk kepada keadaan yang susah tidur karena mendengar suara burung. Penafsiran "pendengaran yang melemah" dan "keadaan yang susah tidur karena mendengar suara burung" tampaknya berkontradiksi, namun sebenarnya tidak. Seorang tua memang betul pendengarannya akan melemah, tetapi pada saat yang bersamaan ia juga susah tidur. Suara burung yang terdengar tidaklah menyebabkan ia bangun, karena memang ia belum tidur. Kemudian, frasa "semua penyanyi perempuan tunduk" merujuk kepada suara yang tidak didengar dengan jelas lagi.

Pada ayat 5, frasa "orang menjadi takut tinggi, dan ketakutan ada di jalan" merujuk kepada keadaan yang takut ketinggian dan takut untuk bepergian, "pohon badam berbunga" merujuk kepada rambut putih yang tumbuh pada orang yang sudah tua, "belalang menyeret dirinya dengan susah payah" merujuk kepada pergelangan kaki yang tidak mampu berjalan lagi, "nafsu makan tak dapat dibangkitkan lagi" merujuk kepada nafsu seksual yang tidak ada lagi.

Dari ayat 2 sampai ayat 5 ini menggambarkan proses penuaan yang dialami oleh seorang manusia. Sampai pada akhirnya, ia masuk ke dalam "rumahnya yang kekal", yaitu kuburan itu sendiri. Selanjutnya pada ayat 6, Gordis menyatakan "there is only one figure here, that of a well, worked by a cord tied to a wheel. One end of the cord has a pitcher, the other a metal ball as a counterweight. When the cord is torn, ball, pitcher, and wheel all fall to the bottom and are broken." 45 Dengan kata lain, ayat 6 ini menggambarkan kematian yang akan dihadapi oleh orang yang telah mengalami proses penuaan tersebut. Peristiwa kematian ini makin diperjelas lagi pada ayat 7, yaitu debu kembali menjadi tanah seperti semula, dan roh kembali kepada Allah yang mengaruniakannya.

\section{Analisis Inner-Textuality Kitab Pengkhotbah \\ Latar Belakang Penulisan Kitab Pengkhotbah}

Kitab Pengkhotbah memiliki latar belakang yang pelik. Sebagian orang menganggap bahwa kitab ini ditulis pada masa prapembuangan. ${ }^{46} \mathrm{Hal}$ ini dikarenakan adanya dugaan bahwa kitab ini ditujukan kepada orang-orang yang memiliki raja/penguasa. Qoheleth sedemikian rupa menasihati pembacanya untuk menaati raja (Pkh. 4:13-16; 8:2-8; 10:47, 16-20). Namun, pandangan tersebut mendapat banyak perlawanan. Mark Sneed mengatakan bahwa kitab Pengkhotbah ditulis pada masa pascapembuangan. Berkaitan dengan teks-teks yang berhubungan dengan raja/penguasa, ia lebih setuju bahwa hal itu memang dimaksudkan pada era kerajaan Ptolemaic (305 SM - 30 SM). ${ }^{47}$ Selain itu, penggunaan bahasa Ibrani dalam kitab Pengkhotbah juga diduga dipengaruhi oleh bahasa Aram (bahkan ada yang mengatakan bahwa kitab Pengkhotbah adalah terjemahan dari

\footnotetext{
${ }^{45}$ Gordis, Koheleth - The Man and His World, 348.

${ }^{46}$ Greg W. Parsons, "Guidelines for Understanding and Proclaiming the Book of Ecclesiastes, Part 1," Bibliotheca Sacra 160 (Juni 2003): 169.

${ }^{47}$ Mark R. Sneed, “The Social Location of the Book of Qoheleth,” Hebrew Studies 39 (1998): 50-51.
} 
bahasa Aram), persamaan dengan bahasa Ibrani Mishnaic, beberapa pinjaman kata dari bahasa Persia, dan pengaruh bahasa Fenisia dan Yunani. Pengaruh bahasa-bahasa tersebut membuktikan bahwa kitab Pengkhotbah setidaknya ditulis pada masa pascapembuangan, yaitu antara sekitar tahun 500 SM sampai 150 SM. 48

Di samping itu, kitab Pengkhotbah diyakini ditulis dengan tujuan untuk melawan pengaruh filsafat Epikureanisme, yaitu yang mengajarkan tujuan Allah bagi dunia sepenuhnya tidak dapat dimengerti dan penuh dengan teka-teki. ${ }^{49}$ Tetapi, di sisi lain Qoheleth tampaknya juga mengutip filsafat Epikureanisme yang mengajarkan manusia untuk mengejar kesenangan semata $(2: 24-26 ; 3: 12-13,22 ; 5: 17-19 ; 7: 14 ; 8: 15 ; 9: 7-10$; 11:7-12:7). ${ }^{50}$ Bagaimanapun, hal-hal tersebut menunjukkan bahwa kitab Pengkhotbah memang ditulis pada masa pascapembuangan.

Penulis sendiri setuju dengan pandangan bahwa kitab Pengkhotbah ditulis pada masa pascapembuangan. Hal ini dikarenakan orang-orang Israel pascapembuangan cenderung memikirkan ulang akan kehidupan yang mereka jalani selama ini. Pemikiran dan perenungan mereka inilah yang menghasilkan banyak sekali tulisan-tulisan hikmat. Dalam tulisan-tulisan tersebut, orang-orang bijaksana ini mulai mempertanyakan bagaimana sistem kehidupan ini berjalan. Di tengah situasi yang seperti ini, muncullah Qoheleth yang memberikan pandangan yang berlawanan dengan pandangan tradisional yang selama ini diyakini orang Israel, bahwa orang benar akan selalu mendapatkan kehidupan yang baik dan orang jahat akan selalu mendapatkan kehidupan yang buruk. Sebaliknya, Qoheleth melihat kenyataan yang terjadi, dan menyimpulkan bahwa tidak selalu orang benar akan menerima hidup yang baik, dan tidak selalu pula orang jahat akan menerima kehidupan yang buruk (Pkh. 7:15).

\section{Siapakah Qoheleth?}

Tentang siapakah Qoheleth memicu banyak perdebatan. Pandangan tradisional menyatakan bahwa Qoheleth adalah Salomo. Ada beberapa bukti yang mendukung pandangan ini. ${ }^{51}$ Pertama, ada klaim yang eksplisit bahwa yang menulis adalah anak Daud (Pkh. 1:1). Kedua, hanya Salomo yang memenuhi deskripsi sebagai seorang yang paling berhikmat dan kaya serta memiliki banyak istri (Pkh. 1:16; 2:4-11). Ketiga, kitab ini memiliki kesamaan tema dengan kitab Amsal, yaitu sama-sama bertema "takut akan Tuhan" (Pkh. 10:8, 9, 12, 13, 18; 12:9).

\footnotetext{
${ }^{48}$ Martin A. Shields, The End of Wisdom: A Reappraisal of the Historical and Canonical Function of Ecclesiastes (Winona Lake: Eisenbrauns, 2006), 22-23.

${ }^{49}$ Craig G. Bartholomew, Reading Ecclesiastes: Old Testament Exegesis and Hermeneutical Theory, Analecta Biblica 139 (Roma: Pontificio Istituto Biblico, 1998), 263.

50Shields, The End of Wisdom, 27-28.

${ }^{51}$ Norman L. Geisler, A Popular Survey of the Old Testament (Grand Rapids: Baker Books, 1998), $213-214$
} 
Namun, pandangan tradisional telah banyak ditinggalkan. Di satu sisi, bukti internal menunjukkan bahwa nama Salomo sendiri tidak pernah tertulis secara eksplisit di kitab Pengkhotbah. Selain itu, Pengkhotbah 1:16 mencatat "lebih dari pada semua orang yang memerintah atas Yerusalem sebelum aku." Siapakah orang-orang yang pernah menjadi raja atas Yerusalem sebelum Salomo? Sejarah mencatat hanya Daud yang pernah menjadi raja atas Yerusalem sebelum Salomo. Oleh karena itu, menjadi aneh apabila dikatakan bahwa Qoheleth lebih berhikmat dari pendahulu-pendahulunya, sebab pendahulunya baru hanya satu orang. Selanjutnya, pada Pengkhotbah 1:12 dikatakan bahwa "Aku, Qoheleth adalah (was) raja atas Israel di Yerusalem." Bentuk lampau dari kalimat itu mengindikasikan bahwa Qoheleth sekarang tidak lagi menjadi raja atas Israel. Hal ini tidak sesuai dengan raja Salomo yang tetap menjadi raja sampai akhir hidupnya.

Di sisi lain, bukti eksternal menunjukkan bahwa bahasa-bahasa yang digunakan oleh Qoheleth tidak merujuk kepada bahasa-bahasa yang digunakan pada zaman Salomo.52 Sebaliknya, seperti yang sudah disebutkan di atas, bahasa-bahasa yang digunakan merujuk pada bahasa-bahasa pada tahun tidak lebih awal dari 500 SM. Dengan demikian, dapat disimpulkan bahwa Qoheleth sebenarnya bukanlah raja Salomo. Ia hanya mengambil persona Salomo untuk mendapatkan otoritas agar apa yang dikatakannya mendapat perhatian dari orang-orang.

\section{Struktur Kitab Pengkhotbah}

Secara umum, kitab Pengkhotbah dapat dibagi menjadi tiga bagian besar, yaitu: bagian prolog (1:1-1:11), bagian isi (1:12-12:7), dan bagian epilog (12:8-14). Terdapat perbedaan subjek yang dipakai antara bagian prolog dan epilog dengan bagian isi. Bagian prolog dan epilog memakai subjek orang ketiga, sedangkan bagian isi memakai subjek orang pertama (meskipun ada pengecualian pada 7:27). Perbedaan jenis subjek yang dipakai ini tentu mengindikasikan ada lebih dari satu pengarang yang melakukan pergantian subjek secara sengaja. ${ }^{53}$ Hal ini terlihat juga pada pasal 7:27, di mana pengarang secara tiba-tiba mengganti subjeknya menjadi orang ketiga, lalu menggantinya kembali menjadi orang pertama. Dengan kata lain, memang setidaknya ada lebih dari satu pengarang yang terlibat dalam penulisan kitab Pengkhotbah, yaitu Qoheleth yang menulis bagian isi, dan sang narator yang mengumpulkan tulisan-tulisan Qoheleth serta membingkainya dalam tujuan penulisannya sendiri di bagian prolog dan epilog.

\section{Nuansa Kitab Pengkhotbah}

Ada banyak perdebatan berkaitan dengan nuansa dari kitab Pengkhotbah. Crenshaw mengungkapkan bahwa Qoheleth memiliki pandangan dunia bahwa hidup itu tidak

${ }^{52}$ C. L. Seow, Ecclesiastes: A New Translation With Introduction and Commentary, ed. ke-1, The Anchor Bible 18C (New York: Doubleday, 1997), 11.

${ }^{53}$ Michael V. Fox, "Frame-Narrative and Composition in the Book of Qohelet," Hebrew Union College Annual 48 (1977): 84. 
menguntungkan dan benar-benar tidak masuk akal. ${ }^{4}$ Hal ini terlihat dari kebajikankebajikan yang tidak mendatangkan pahala, Allah yang berdiri jauh-jauh dan meninggalkan manusia kepada kebetulan serta kematian. Lebih lanjut, Scott juga melihat hal yang serupa, bahwa Qoheleth menawarkan filsafat agnostik, pesimistis dan pengunduran diri. ${ }^{55}$ Bahkan lebih jauh lagi, Frank Zimmerman menyatakan bahwa Qoheleth adalah seorang neurotik dan peragu patologis yang meragukan dirinya sendiri sebagai orang yang berharga dan berkarakter. ${ }^{56}$

Namun demikian, penulis berargumen bahwa kitab Pengkhotbah adalah kitab yang bernuansa realistis. Qoheleth adalah seorang realis yang melihat apa yang terjadi "di bawah matahari" sama sekali bertentangan dengan optimisme yang diberikan oleh traditional wisdom, yang mengatakan bahwa orang benar akan selalu menerima hidup yang baik, sedangkan orang yang jahat akan selalu menerima hidup yang buruk. ${ }^{57}$ Selain itu, Qoheleth juga melihat bahwa hikmat yang paling dibanggakan oleh manusia selama ia hidup tetap memiliki keterbatasan karena tidak dapat menjelaskan ketidakteraturan yang terjadi di dunia. ${ }^{58}$ Namun bagaimanapun, hikmat memberikan keuntungan bagi manusia (Pkh. 7:11). Keuntungan yang dimaksud bukanlah untuk melindungi dari kematian, sebab baik yang bijaksana maupun yang bodoh sama-sama akan menghadapi kematian. Keuntungan yang dimaksud adalah untuk memberikan bimbingan selama hidup di dunia. ${ }^{59}$

\section{Konsep Kematian dan Kenikmatan (Enjoyment) Dalam Kitab Pengkhotbah}

Qoheleth berulang kali mengatakan bahwa kematian akan meniadakan semua keberhasilan yang dicapai oleh manusia, dan karena itu semua hal adalah sia-sia. Namun di tengah-tengah perkataannya tentang kematian, ia juga memberikan nasihat untuk menikmati hasil kerja keras yang telah dilakukan. Kedua hal ini tampaknya kontradiksi, tetapi sebenarnya tidak dapat dipisahkan satu sama lain. Tabel berikut ini akan memberikan hubungan antara pemahaman Qoheleth tentang kematian dan menikmati hasil kerja keras. Hubungan antara kematian dan menikmati hasil kerja keras memperlihatkan bahwa dengan menyadari adanya kematian, maka hidup akan menjadi berarti.

\footnotetext{
54James L. Crenshaw, Ecclesiastes: A Commentary, Old Testament Library (Philadelphia: Westminster Press, 1987), 23.

${ }^{55}$ Scott, Proverbs, Ecclesiastes, 191.

${ }^{56}$ Frank Zimmermann, The Inner World of Qohelet (New York: Ktav Pub. House, 1973), 8.

${ }^{57}$ Roy B. Zuck, “God and Man in Ecclesiastes,” Bibliotheca Sacra 148 (Maret 1991): 49.

${ }^{58}$ Neal David Williams, A Biblical Theology of Ecclesiastes (Ann Arbor: University Microfilms International, 1986), 85-86.

${ }^{59}$ James F. Armstrong, "Ecclesiastes in Old Testament Theology," Princeton Seminary Bulletin 4, no. 1 (1983): 18.
} 
Tabel 1 Hubungan antara Kematian dan Kenikmatan dalam Kitab Pengkhotbah 60

\begin{tabular}{|c|c|c|c|}
\hline $\begin{array}{c}\text { Pandangan tentang } \\
\text { Kematian }\end{array}$ & Isu terkait kematian & Peran Allah & Kepunyaan \\
\hline \multirow[t]{2}{*}{$\begin{array}{c}\text { Ketidakpastian akan } \\
\text { warisan }(2: 18-21)\end{array}$} & $\begin{array}{c}\text { Kesia-siaan kerja } \\
\text { keras }(1: 18-19,22- \\
23)\end{array}$ & $\begin{array}{c}\text { Kepunyaan adalah } \\
\text { pemberian Allah } \\
(2: 24-26)\end{array}$ & $\begin{array}{c}\text { Menikmati } \\
\text { kesenangan } \\
(2: 24 \mathrm{a})\end{array}$ \\
\hline & & $\begin{array}{c}\text { Allah yang tidak dapat } \\
\text { dimengerti }(3: 11) . \\
\text { Kepunyaan adalah } \\
\text { pemberian Allah } \\
(3: 13)\end{array}$ & $\begin{array}{c}\text { Menikmati } \\
\text { kesenangan } \\
(3: 12)\end{array}$ \\
\hline $\begin{array}{c}\text { Dalam kematian } \\
\text { semua kembali } \\
\text { kepada debu (3:19- } \\
\text { 20) }\end{array}$ & $\begin{array}{l}\text { Ketidakpastian hari } \\
\text { esok }(3: 22 \mathrm{~b})\end{array}$ & & $\begin{array}{c}\text { Menikmati } \\
\text { kesenangan } \\
(3: 22 a)\end{array}$ \\
\hline $\begin{array}{l}\text { Ketidakpastian akan } \\
\text { warisan }(5: 12-13)\end{array}$ & $\begin{array}{c}\text { Tidak ada satupun } \\
\text { yang dapat dibawa } \\
(5: 14-15)\end{array}$ & $\begin{array}{c}\text { Kehidupan dan } \\
\text { kepunyaan adalah } \\
\text { pemberian Allah } \\
(5: 17-18 ; 6: 2)\end{array}$ & $\begin{array}{c}\text { Menikmati } \\
\text { kesenangan } \\
(5: 17)\end{array}$ \\
\hline $\begin{array}{c}\text { Orang benar } \\
\text { maupun orang fasik } \\
\text { akan mengalami } \\
\text { kematian }(8: 14)\end{array}$ & $\begin{array}{c}\text { Seseorang tidak } \\
\text { dapat mengendalikan } \\
\text { kematian }(8: 8,13) \\
\text { atau bagaimana ia } \\
\text { akan dikenang }(8: 10)\end{array}$ & $\begin{array}{c}\text { Allah adalah Pemberi } \\
\qquad(8: 15)\end{array}$ & $\begin{array}{c}\text { Menikmati } \\
\text { kesenangan } \\
(8: 15)\end{array}$ \\
\hline $\begin{array}{c}\text { Kematian akan } \\
\text { menjadi nasib akhir } \\
\text { orang benar maupun } \\
\text { orang fasik (9:1-3) }\end{array}$ & $\begin{array}{c}\text { Kematian } \\
\text { menghancurkan } \\
\text { pengetahuan, ingatan, } \\
\text { emosi }(9: 5-6,10)\end{array}$ & $\begin{array}{c}\text { Allah berkenan } \\
\text { manusia menikmati } \\
\text { kesenangan }(9: 7)\end{array}$ & $\begin{array}{c}\text { Menikmati } \\
\text { kesenangan } \\
(9: 7-10)\end{array}$ \\
\hline $\begin{array}{l}\text { Kematian dan debu } \\
\text { adalah takdir } \\
\text { universal }(12: 5,7)\end{array}$ & $\begin{array}{c}\text { Ketidaksanggupan } \\
\text { untuk menikmati } \\
\text { masa tua (12:1-5). } \\
\text { Hari-hari yang gelap } \\
\text { akan tiba (11:8) }\end{array}$ & $\begin{array}{c}\text { Allah memberikan } \\
\text { nafas kehidupan } \\
\text { (12:7). } \\
\text { Allah akan mengadili } \\
\text { segala sesuatu (11:9) }\end{array}$ & $\begin{array}{c}\text { Menikmati } \\
\text { kesenangan } \\
(11: 8-9)\end{array}$ \\
\hline
\end{tabular}

\section{Konsep Kehidupan Setelah Kematian Menurut Kitab Pengkhotbah}

Di dalam tulisan Qoheleth sendiri tampaknya sulit untuk mengetahui perspektifnya tentang kehidupan setelah kematian. Oleh karena itu, diperlukan peninjauan lebih lanjut terhadap apa yang dikatakan oleh narator yang berbicara secara khusus pada bagian

${ }^{60}$ Matthew S. Rindge, "Mortality and Enjoyment: The Interplay of Death and Possessions in Qoheleth," Catholic Biblical Quarterly 73, no. 2 (April 2011): 279. 
epilog sebab bagian tersebut mengindikasikan adanya "pengadilan" yang akan terjadi pada setiap orang yang telah mati (Pkh. 12:14). ${ }^{61}$

Pada bagian epilog juga tampak ada indikasi kehidupan setelah kematian. Di sini narator menyimpulkan bahwa pada akhirnya akan ada pengadilan bagi semua orang. Memang, bagian ini tidak terlalu jelas menunjukkan bagaimana kondisi manusia setelah kematian. Tetapi, yang jelas bahwa akan ada pengadilan bagi manusia yang tentunya hidup. Lagipula, pada Pengkhotbah 12:7 Qoheleth mengatakan bahwa roh manusia akan kembali kepada Allah yang mengaruniakan. Dalam hal ini, kematian menjadi cara supaya manusia dapat datang mendekat pada Allah. Graham Ogden juga berkata bahwa "Reversing the process of original creation would seem to imply that Qoheleth [the Teacher] reasons that death will not separate us from God; rather, at that moment we return to his presence." 62

Di sisi lain, kematian juga dipandang sebagai hal yang membawa kebahagiaan sebab akan meniadakan setiap persoalan hidup manusia. Hal ini terlihat jelas pada perkataannya: "Oleh sebab itu aku menganggap orang-orang mati, yang sudah lama meninggal, lebih bahagia dari pada orang-orang hidup, yang sekarang masih hidup." (Pkh. 4:2). Demikian juga yang disimpulkan oleh David L. Smith bahwa "death brings the removal of that weight, the relief of persecution, for it is rest." 63

Dengan demikian, dapat disimpulkan bahwa kematian bagi kitab Pengkhotbah memang adalah akhir dari kehidupan di dunia dan bahkan dianggap sebagai kebahagiaan. Tetapi, hal tersebut tidak berhenti sampai di situ saja. Ada indikasi kehidupan selanjutnya ketika Allah mengadili setiap perbuatan manusia, entah itu baik atau jahat.

\section{Analisis Inter-Textuality Kitab Pengkhotbah Dengan Kitab-Kitab Lain}

Analisis inter-textuality akan membuktikan bahwa apa yang menjadi pemahaman kitab Pengkhotbah tentang kehidupan sejalan dengan pemahaman teks-teks di kitab-kitab lain. Analisis ini akan didasari pada pendekatan kanonik. ${ }^{64}$ Oleh karena itu, penulis akan

\footnotetext{
${ }^{61}$ Hubungan antara bagian epilog dan Qoheleth menimbulkan perdebatan. Apakah narator pada bagian epilog sama sekali memiliki perspektif yang berbeda dengan Qoheleth? Apakah narator justru sangat mendukung perspektif Qoheleth? Sebenarnya ada berapa narator epilog, satu orang ataukah dua orang? Penulis sendiri setuju dengan pandangan yang mengatakan bahwa hanya ada satu narator epilog. Pemberian pujian dan kritikan terhadap kata-kata Qoheleth wajar saja diberikan dengan hanya oleh satu orang. Selain itu, narator juga sebenarnya mendukung apa yang menjadi pandangan Qoheleth, hanya saja ia memperluas konteks dan perspektifnya secara teologis. Lihat Peter Enns, " Qohelet's Wisdom in Qoh. 12:13 or 'The "A is so, and What's More, B" Theology of Ecclesiastes,"' dalam The Idea of Biblical Interpretation: Essays in Honor of James L. Kugel, ed. Hindy Najman dan Judith H. Newman (Leiden: Brill, 2004), 137.

${ }^{62}$ Graham S. Ogden, Qoheleth, ed. ke-2, Readings, A New Biblical Commentary (Sheffield: Sheffield Phoenix Press, 2007), 207.

${ }^{63}$ David L. Smith, "The Concept of Death in Job and Ecclesiastes," Didaskalia 4, no. 1 (1992): 9.

${ }^{64}$ Kanonikal berarti bentuk literer aktual dari tiap kitab dalam Alkitab yang disusun secara intensional dan teologis. Penjelasan lebih lanjut dapat ditelusuri dalam Walter Brueggemann, Theology of the Old Testament: Testimony, Dispute, Advocacy (Minneapolis: Fortress Press, 1997), 89-90.
} 
terlebih dahulu menunjukkan bahwa kitab Pengkhotbah termasuk ke dalam kanon Ibrani di tengah segala perdebatan yang ada.

\section{Kitab Pengkhobah Dalam Kanon Ibrani65}

Bagi orang Yahudi, untuk dianggap sebagai bagian dari kanon, sebuah kitab harus dipandang sebagai panduan otoritatif untuk tradisi Yahudi, dinilai mengikat selamanya, dan terus-menerus menjadi sumber pembelajaran bagi komunitas. ${ }^{66}$ Meskipun kitab Pengkhotbah sempat dipertanyakan keberadaannya di dalam kanon Yahudi ${ }^{67}$ namun pada kenyataannya, berdasarkan kategori di atas, kitab Pengkhotbah cocok untuk dimasukkan ke dalam kanon.

Namun, yang menjadi persoalan adalah apakah seluruh isi kitab Pengkhotbah diinspirasikan secara ilahi oleh Allah, atau hanya merupakan pemikiran-pemikiran dari penulisnya. ${ }^{68}$ Terlepas dari seluruh perdebatan tentang inspirasi, kitab Pengkhotbah tetap dapat dimasukkan ke dalam kanon Ibrani karena memiliki keterkaitan dengan Taurat, kitab para nabi, dan kumpulan tulisan-tulisan.69 Pada bagian epilog, narator mengungkapkan frasa "takutlah akan Allah" (Pkh. 12:13). Frasa ini mengindikasikan adanya persamaan dengan kumpulan tulisan-tulisan dalam kitab Amsal dan Ayub. Lebih lanjut, ungkapan "berpeganglah pada perintah-perintah-Nya" (Pkh. 12:13) juga mengindikasikan adanya keterkaitan dengan Taurat sebagai kumpulan perintah Allah. Selanjutnya, narator juga mengingatkan pembacanya bahwa Allah akan membawa setiap perbuatan ke pengadilan (Pkh. 12:14). Dengan demikian, narator mau agar pembacanya hidup saat ini dengan perspektif masa depan. Sikap hidup yang demikian seringkali juga digaungkan oleh para nabi yang mengatakan bahwa Allah akan membawa penghakiman kepada setiap perbuatan manusia. Jadi, dari sini dapat dilihat ada keterkaitan antara kitab Pengkhotbah dengan kitab para nabi. Dengan kata lain, kitab Pengkhotbah cocok dengan kanon Ibrani.

\footnotetext{
${ }^{65}$ Kanon Ibrani dibagi menjadi tiga bagian besar yaitu: תוֹרָה (Pentateuch), נְבְיאים (the prophets), dan

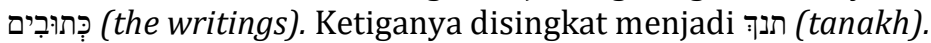

${ }^{66}$ Shnayer Z. Leiman, The Canonization of Hebrew Scripture: The Talmudic and Midrashic Evidence (Hamden: Archon, 1976), 119.

${ }^{67}$ John Jarrick, seorang sarjana Perjanjian Lama, mengatakan bahwa kitab Pengkhotbah adalah kitab yang kontroversial secara historis karena kata-kata Qoheleth dianggap bidah yang berbahaya, tampaknya mempertanyakan ajaran tradisional tentang keadilan ilahi dan mengajarkan pendekatan carpe diem terhadap kehidupan. Lih. J. Jarick, "Theodore of Mopsuestia and the Interpretation of Ecclesiastes," dalam The Bible in Human Society: Essays in Honour of John Rogerson, ed. M. Daniel Carroll R., David J. A. Clines, dan Philip R. Davies, Journal for the Study of the Old Testament Supplement Series 200 (Sheffield: Sheffield Acad. Press, 1995), 306.

${ }^{68}$ Ruth Sandberg, "Qohelet and the Rabbis," dalam The Words of the Wise Are like Goads: Engaging Qohelet in the 21st Century, ed. Mark J. Boda, Tremper Longman III, dan Cristian G. Rata (Winona Lake: Eisenbrauns, 2013), 37.

${ }^{69}$ Longman III, The Book of Ecclesiastes, 39.
} 
Kanon Ibrani memasukkan kitab Pengkhotbah ke dalam kumpulan tulisan-tulisan

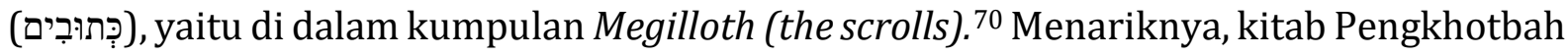
setiap tahunnya dibacakan pada hari raya Sukkot (hari raya Pondok Daun). Sebenarnya tidak ada alasan yang terlalu jelas mengapa kitab Pengkhotbah dibacakan pada hari raya tersebut. Fox mengatakan bahwa kemungkinan besar hal ini dikarenakan Qoheleth menganjurkan untuk bersukacita menikmati kesenangan, yang sesungguhnya menjadi suasana hati dari Sukkot, dan bahwa ia mendeklarasikan kefanaan hidup manusia, yang dilambangkan dengan baik oleh bilik sementara dan musim gugur yang membangkitkan kematian. ${ }^{71}$ Di dalam kitab Ulangan 16:14, Allah memerintahkan Israel untuk

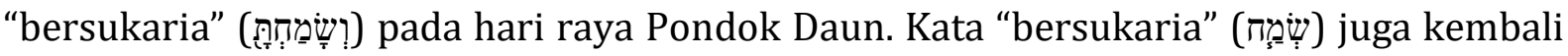
diulang oleh Qoheleth dalam kitab Pengkhotbah (Pkh. 3:12; 5:18; 9:7; 11:9). ${ }^{72}$ Dengan demikian, kitab Pengkhotbah dianggap sebagai kitab yang bersukacita dan karena itu dibacakan pada hari raya Sukkot.

\section{Hubungan Intertekstualitas Kitab Pengkhotbah dengan Ayub dan Amsal}

Para ahli sepakat bahwa kitab Pengkhotbah bersama dengan Amsal dan Ayub digolongkan sebagai literatur hikmat. Tema utama yang sama di antara ketiga kitab tersebut adalah tentang "takut akan Allah" (Ams. 1:7; Ayb. 28:28; Pkh. 12:13). Selain itu, ketiganya juga mengecam adanya penindasan, ketidakadilan, dan pelanggaranpelanggaran terhadap hukum Allah. Mereka juga mengaitkannya pada realitas penghakiman yang menunggu setiap manusia yang berdosa. ${ }^{73}$

Di sisi lain, kitab Ayub dan Pengkhotbah sendiri tampaknya memiliki kesamaan yang melawan pandangan kitab Amsal terhadap kehidupan. Amsal mengatakan bahwa orang benar akan mendapatkan kehidupan yang baik, sedangkan orang jahat akan mendapatkan kehidupan yang buruk. ${ }^{74}$ Namun, Ayub dan Pengkhotbah melawan prinsip ini. Pengkhotbah lebih memikirkan prinsip dasarnya, bahwa semua orang pada akhirnya akan menghadapi kematian, baik orang baik maupun orang jahat. Sementara itu, Ayub menjadi salah satu contoh nyata di mana orang baik mendapatkan kehidupan yang buruk.

Selanjutnya, kitab Amsal dan Pengkhotbah sendiri memiliki hubungan yang menarik. Amsal mengatakan bahwa "takut akan TUHAN adalah permulaan hikmat" (Ams. 1:7). Sementara itu, kitab Pengkhotbah mengatakan bahwa "akhir dari segala yang

\footnotetext{
${ }^{70}$ Megilloth merupakan kumpulan lima gulungan tulisan, yaitu kitab Kidung Agung, Rut, Ratapan, Pengkhotbah, dan Ester. Kesamaan dari kelima gulungan tulisan ini adalah mereka sama-sama dibacakan di publik pada hari-hari raya tahunan orang Yahudi: kitab Rut dibacakan pada Feast of Weeks (Pentecost), Kidung Agung pada Passover festival, Pengkhotbah pada Feast of Tabernacles (hari raya Sukkot), Ratapan pada peringatan penghancuran Yerusalem yang terjadi pada tahun 587 SM, Ester pada hari raya Purim. 2004), xv.

${ }^{71}$ Michael V. Fox, Ecclesiastes, JPS Bible Commentary (Philadelphia: Jewish Publication Society,

${ }^{72}$ Sandberg, "Qohelet and the Rabbis," 53.

${ }^{73}$ Paul R. House, Old Testament Theology (Downers Grove: Inter-Varsity Press, 1998), 481.

${ }^{74} \mathrm{Hal}$ ini juga disebut sebagai retributive theology.
} 
didengar [hikmat] ialah takut akan Allah" (Pkh. 12:13). Melihat hal ini, Genhard von Rad berkata "the statement that the fear of God is the beginning of wisdom could even be turned around, to the effect that knowledge and experience lead to the fear of God."75 Lebih lanjut, Stephen G. Dempster menggunakan skema "orientation-disorientation-reorientation"yang diusulkan oleh Walter Brueggemann untuk memahami kitab Mazmur—sebagai cara untuk memahami hubungan kitab Amsal dan Pengkhotbah. Ia mengatakan: ${ }^{76}$

At the beginning, the believer is profoundly oriented by the fear of God, and this stance leads to the journey through Proverbs. There is solidity, stability, regularity, and order. But this is not the end of the wisdom journey. It must continue to the world of Eccelesiastes with its chaos, its injustice, its violence, its death, and its -its intense disorientation. However, at the end of this journey, one returns to the beginning - but it is a different beginning; it is a profound reorientation. The words are the same, but everything is different.

Dengan demikian, sebenarnya hubungan antara kitab Amsal dan Pengkhotbah bukanlah hubungan yang saling berkontradiksi. Namun, kedua kitab tersebut memiliki hubungan yang saling melengkapi (komplementer).

\section{Hubungan Intertekstualitas Kitab Pengkhotbah dengan Kejadian}

Setidaknya ada dua teks dalam Pengkhotbah yang memiliki gema terhadap peristiwa penciptaan, yaitu pada Pengkhotbah 3:20 dan 12:7 yang adalah gema dari Kejadian 2:7 dan 3:19.77 Selain itu, perikop-perikop tentang "menikmati kesenangan" (enjoyment) dalam kitab Pengkhotbah (Pkh. 2:24-26; 3:10-15; 3:16-22; 5:17-19; 9:7-10; 11-7:10) memiliki beberapa kata yang mirip dengan kata-kata yang dipakai di dalam Kejadian 2. Di dalam Kejadian 2:15, Allah menempatkan manusia di taman Eden untuk mengusahakan dan memelihara taman itu. Selanjutnya, Allah memberi manusia (הָאזָזָם ) perintah untuk makan (תאמָל) dari semua pohon yang ada di taman itu, kecuali pohon pengetahuan yang

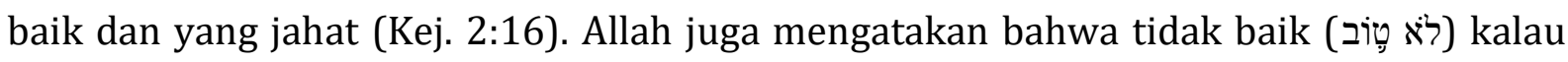
manusia sendiri saja, sehingga Ia pun menciptakan perempuan (אִ: (Kej. 2:23). Setidaknya, pada perikop Kejadian 2 ini, ada empat kata yang juga dipakai di dalam

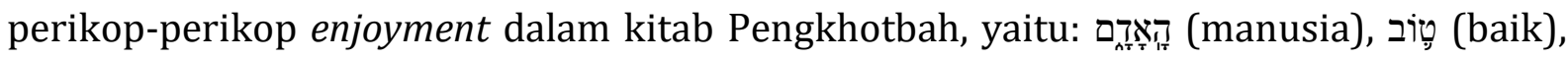

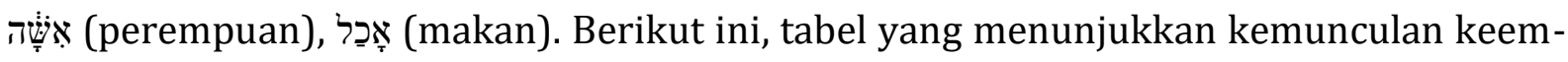
pat kata-kata tersebut dalam perikop-perikop enjoyment dalam kitab Pengkhotbah: ${ }^{78}$

Tabel 2 Lokasi Kemunculan Kata "Manusia”, "Baik”, "Perempuan” dan "Makan”

\begin{tabular}{|l|c|c|c|c|c|c|}
\hline Qoheleth & $2: 24-26$ & $3: 10-15$ & $3: 16-22$ & $5: 17-19$ & $9: 7-10$ & $11: 7-10$ \\
\hline
\end{tabular}

${ }^{75}$ Gerhard Von Rad dan James D. Martin, Wisdom in Israel (London: Xpress Reprints, 1997), 194.

${ }^{76}$ Stephen G. Dempster, "Ecclesiastes and the Canon," dalam The Words of the Wise Are like Goads: Engaging Qohelet in the 21st Century, ed. Mark J. Boda, Tremper Longman III, dan Cristian G. Rata (Winona Lake: Eisenbrauns, 2013), 398-399.

${ }^{77}$ Russell L. Meek, "The Meaning of הַָבר in Qohelet: An Intertextual Suggestion," dalam The Words of the Wise Are like Goads: Engaging Qohelet in the 21st Century, ed. Mark J. Boda, Tremper Longman III, dan Cristian G. Rata (Winona Lake: Eisenbrauns, 2013), 249.

${ }^{78}$ Ibid., 251. 


\begin{tabular}{|c|c|c|c|c|c|c|}
\hline הָאָאדָם & $\sqrt{ }$ & $\sqrt{ }$ & $\sqrt{ }$ & $\sqrt{ }$ & & $\sqrt{ }$ \\
\hline טֶטוֹב & $\sqrt{ }$ & $\sqrt{ }$ & $\sqrt{ }$ & $\sqrt{ }$ & $\sqrt{ }$ & $\sqrt{ }$ \\
\hline אְִָָּּׁה & & & & & $\sqrt{ }$ & \\
\hline אָכָל & $\sqrt{ }$ & $\sqrt{ }$ & & $\sqrt{ }$ & $\sqrt{ }$ & \\
\hline
\end{tabular}

Melalui kesamaan beberapa kata tersebut, dapat disimpulkan bahwa Qoheleth sebenarnya mau mengajak pembacanya untuk dapat memiliki enjoyment di dunia ini seperti enjoyment yang dimiliki oleh Adam dan Hawa saat berada di taman Eden. ${ }^{79}$

Selain itu, kata הֶֶר ("vanity," "wind," "vapor," "breath," "meaningless," "absurd," "ephemeral") yang disebutkan berulang-ulang oleh Qoheleth, merupakan kata yang sama

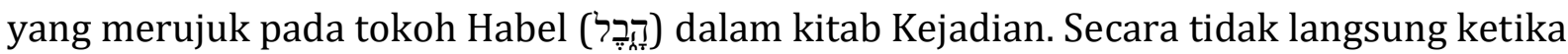
Qoheleth menyebutkan kata הֶֶ, ia mau menunjukkan bahwa realitas yang terjadi "di bawah matahari" ini adalah sama dengan realitas yang dialami oleh Habel, yaitu orang yang baik seperti Habel pada akhirnya mendapatkan konsekuensi yang buruk (dibunuh oleh kakaknya sendiri). ${ }^{80}$ Selain itu, Qoheleth juga mau menunjukkan betapa sementaranya hidup manusia (הֶָר) sama seperti hidup Habel yang begitu singkat. ${ }^{81}$

\section{Kitab Pengkhotbah dan Kristus}

Dalam keseluruhan kitab Pengkhotbah, Qoheleth tampak seperti masuk ke dalam masa disorientation $^{82}$ di mana kematian meniadakan segala sesuatu. Ia melihat segala sesuatu secara realistis sebagaimana adanya realitas kematian itu sendiri. Kematian tidak dapat terhindarkan. Walaupun demikian, dalam Perjanjian Baru ada seseorang yang lebih besar dari Qoheleth, yaitu Yesus Kristus yang juga telah masuk ke dalam masa disorientation itu, bahkan mati bagi semua orang. 83 Tetapi, kematian tidak dapat mengalahkan Yesus Kristus. Ia bangkit pada hari yang ke-3 dan menunjukkan bahwa kematian bukanlah akhir dari segala sesuatu. Lebih daripada itu, kebangkitan-Nya menunjukkan bahwa kuasa kematian telah dikalahkan-Nya.

Meskipun demikian, bayang-bayang kematian (mis.: penderitaan, kejahatan, bencana alam, dll.) masih menghantui kehidupan manusia, termasuk menghantui mereka yang sudah percaya kepada Kristus (Rm. 8:18, 20). Hal inilah yang disadari penuh dan

${ }^{79}$ Ibid., 252.

80Ibid., 255.

${ }^{81}$ Benjamin Shaw, "On Reading Ecclesiastes," dalam The Hope Fulfilled: Essays in Honor of O. Palmer Robertson, ed. Robert L. Penny (Phillipsburg: P\&R Publishing Company, 2008), 56. Mazmur.

${ }^{82}$ Penulis meminjam istilah yang diperkenalkan oleh Walter Brueggemann untuk memahami kitab

${ }^{83}$ Dempster, “Ecclesiastes and the Canon," 399. 
tidak diabaikan oleh Qoheleth sebagai seorang realis. ${ }^{84}$ Tetapi, dengan kemenangan Kristus atas kuasa kematian, orang yang percaya kepada-Nya akan dimampukan untuk melihat jauh ke depan bahwa penderitaan yang dialami di dunia ini, termasuk kematian bukanlah akhir dari segala sesuatu. Barangsiapa yang percaya kepada Kristus akan bangkit setelah mati dan hidup untuk selama-lamanya (Yoh. 11:25-26).

Lebih lanjut, orang-orang yang bangkit dari kematian akan mengalami pengadilan Allah (Pkh. 3:17; 11:9; 12:14). Petrus mengatakan bahwa Yesus Kristuslah yang ditentukan oleh Allah untuk menjadi hakim atas orang-orang hidup ${ }^{85}$ dan orang-orang mati (Kis. 10:42; 1 Ptr. 4:5). Setiap perbuatan manusia, entah itu baik atau jahat akan diadili oleh Kristus. Oleh karena itu, manusia hendaknya hidup di dunia ini dengan takut akan Tuhan dan berpegang pada perintah-perintah-Nya, seperti nasihat Qoheleth (Pkh. 12:13).

\section{Kesimpulan}

Melalui tiga analisis yang telah dilakukan di atas, penulis menyimpulkan bahwa Qoheleth tidak memandang kehidupan ini secara pesimis ataupun optimis, melainkan realistis. Qoheleth memandang dan menilai kehidupan ini dengan riil bahwa memang kematian akan menghampiri setiap manusia. Analisis in-textuality pada Pengkhotbah 12:1-7 menunjukkan bahwa Qoheleth menyadari betul bahwa kematian tidak terhindarkan oleh siapapun. Untuk itu, selama masih hidup hendaknya manusia senantiasa mengingat akan akhir kehidupannya. Selanjutnya, analisis inner-textuality pada kitab Pengkhotbah menunjukkan hal yang serupa, bahwa pada kenyataannya kematian akan meniadakan semua pencapaian yang telah diperoleh selama hidup. Walaupun demikian, hikmat tetap dibutuhkan karena memberikan bimbingan selama hidup di dunia. Di bagian epilog narrator memberikan kesimpulan bahwa "akhir dari segala sesuatu adalah: takut akan Allah dan berpegang pada perintah-perintah-Nya" (Pkh. 12:13). Jadi, meskipun kematian tidak terhindarkan oleh setiap manusia, selama hidupnya manusia harus memiliki sikap takut akan Allah dan berpegang pada perintah-perintah-Nya karena Allah akan membawa setiap perbuatan manusia ke dalam pengadilan (Pkh. 12:14).

Berikutnya, analisis inter-textuality Kitab Pengkhotbah dengan kitab Amsal dan Ayub menunjukkan adanya hubungan komplementer di antara ketiganya. Kitab Amsal menyoroti pemahaman tradisional bahwa orang yang berbuat baik akan mendapatkan kehidupan yang baik juga, sementara orang yang berbuat fasik akan mendapatkan kehidupan yang buruk. Tetapi, kitab Ayub melengkapinya dengan menunjukkan bahwa pemahaman tradisional tersebut tidak selalu berjalan mulus, karena pada kenyataannya ada orang yang telah berbuat baik, tetapi mendapatkan kehidupan yang buruk. Kitab

\footnotetext{
${ }^{84}$ Peter Enns, "Ecclesiastes according to the Gospel: Christian Thoughts on Qohelet's Theology," Scripture and Interpretation 2, no. 1 (2008): 37.

85“Orang-orang hidup" di sini berarti orang-orang yang masih hidup ketika Kristus datang kedua kali ke dunia dan menghakimi seluruh manusia.
} 
Pengkhotbah hadir dan memberikan pemahaman yang lebih utuh karena melihat bahwa, baik orang yang berbuat baik selama hidupnya, maupun orang yang berbuat buruk, pada akhirnya keduanya juga akan mengalami kematian. Analisis inter-textuality dengan kitab Kejadian juga menunjukkan bahwa, meskipun kematian bersifat pasti di dalam hidup ini, selama seseorang hidup hendaknya dapat menikmati hidupnya sama seperti Adam dan Hawa yang memiliki enjoyment ketika berada di taman Eden. Kenyataan bahwa hidup ini bersifat sementara seharusnya tidak membuat orang tidak bisa menikmati hidupnya karena kesia-siaan dalam hidup ini telah ditaklukkan oleh Kristus sendiri ketika Ia mati dan bangkit dari kubur-Nya. Sama seperti Ia memiliki kehidupan setelah kematian, demikian juga bagi setiap orang yang percaya pada-Nya akan mempunyai hidup, walaupun ia sudah mati (Yoh. 11:25). Jadi, sebenarnya Kitab Pengkhotbah mengajak para pembacanya agar memiliki perspektif kehidupan setelah kematian selama mereka hidup di dunia. Lebih lanjut, kitab ini dibacakan oleh orang Yahudi pada hari raya Sukkot, yang mana merupakan hari raya yang bersukacita. Dengan demikian, tidak mungkin kitab ini dipahami sebagai kitab yang bernuansa pesimis oleh orang-orang Yahudi.

Implikasi yang dapat ditarik dari hasil penelitian ini adalah bahwa manusia, yang pada dasarnya akan menghadapi realitas kematian, hendaknya tidak menjalani hidup secara optimis berlebihan ataupun pesimis, melainkan realistis. Kematian yang bersifat pasti dan tidak terhindarkan tidak dapat menjadi alasan bagi manusia untuk hidup dengan sembarangan. Kenyataan bahwa di akhir nanti akan ada pengadilan Allah seharusnya membuat manusia hidup dengan takut akan Allah dan senantiasa berpegang pada perintah-perintah-Nya. Hidup yang takut akan Allah itu tidak dijalani dalam ketakutan melainkan pengharapan dan sukacita untuk menikmati anugerah Allah di dalam Kristus yang telah mengalahkan kematian dan menaklukkan kesia-siaan.

\section{Referensi}

Armstrong, James F. "Ecclesiastes in Old Testament Theology." Princeton Seminary Bulletin 4, no. 1 (1983): 16-25.

Bartholomew, Craig G. Reading Ecclesiastes: Old Testament Exegesis and Hermeneutical Theory. Analecta Biblica 139. Roma: Pontificio Istituto Biblico, 1998.

Barton, George A. A Critical and Exegetical Commentary on the Book of Ecclesiastes. The International Critical Commentary 17. New York: Scribner, 1908.

Boda, Mark J. "Speaking into the Silence: The Epilogue of Ecclesiastes." Dalam The Words of the Wise Are like Goads: Engaging Qohelet in the 21st Century, disunting oleh Mark J. Boda, Tremper Longman III, dan Cristian G. Rata, 257-279. Winona Lake: Eisenbrauns, 2013.

Brueggemann, Walter. Theology of the Old Testament: Testimony, Dispute, Advocacy. Minneapolis: Fortress Press, 1997. 
Crenshaw, James L. Ecclesiastes: A Commentary. Old Testament Library. Philadelphia: Westminster Press, 1987.

_-_. Qoheleth: The Ironic Wink. Columbia: University of South Carolina Press, 2013.

Debel, Hans. "When It All Falls Apart: A Survey of the Interpretational Maze Concerning the 'Final Poem' of the Book of Qohelet (Qoh. 12:1-7)." Old Testament Essays 23, no. 2 (2010): 235-260.

Dempster, Stephen G. "Ecclesiastes and the Canon." Dalam The Words of the Wise Are like Goads: Engaging Qohelet in the 21st Century, disunting oleh Mark J. Boda, Tremper Longman III, dan Cristian G. Rata, 387-400. Winona Lake: Eisenbrauns, 2013.

Enns, Peter. "Ecclesiastes according to the Gospel: Christian Thoughts on Qohelet's Theology." Scripture and Interpretation 2, no. 1 (2008): 25-38.

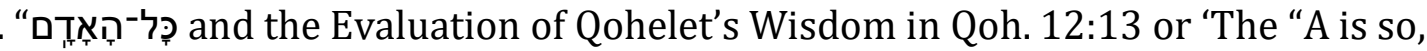
and What's More, B" Theology of Ecclesiastes."' Dalam The Idea of Biblical Interpretation: Essays in Honor of Jame L. Kugel, disunting oleh Hindy Najman dan Judith H. Newman, 125-137. Leiden: Brill, 2004.

Fox, Michael V. Ecclesiastes. JPS Bible Commentary. Philadelphia: Jewish Publication Society, 2004.

- - - "Frame-Narrative and Composition in the Book of Qohelet." Hebrew Union College Annual 48 (1977): 83-106.

- - Q Qohelet and His Contradictions. Journal for the Study of the Old Testament Supplement Series 71. Sheffield: Almond Press, 1989.

Garrett, Duane A. Proverbs, Ecclesiastes, Song of Songs. The New American Commentary 14. Nashville: Broadman Press, 1993.

Geisler, Norman L. A Popular Survey of the Old Testament. Grand Rapids: Baker Books, 1998.

Gordis, Robert. Koheleth - The Man and His World: A Study of Ecclesiastes. Ed. ke-3. New York: Schocken Books, 1968.

House, Paul R. Old Testament Theology. Downers Grove: Inter-Varsity Press, 1998.

Jarick, J. “Theodore of Mopsuestia and the Interpretation of Ecclesiastes." Dalam The Bible in Human Society: Essays in Honour of John Rogerson, disunting oleh M. Daniel Carroll R., David J. A. Clines, dan Philip R. Davies, 200:306-316. Journal for the Study of the Old Testament Supplement Series. Sheffield: Sheffield Acad. Press, 1995.

Keefer, Arthur. "The Meaning of Life in Ecclesiastes: Coherence, Purpose, and Significance from a Psychological Perspective." Harvard Theological Review 112, no. 4 (2019): 447-466. https://doi.org/10.1017/S0017816019000233.

Lee, Eunny P. The Vitality of Enjoyment in Qohelet's Theological Rhetoric. Berlin: Walter de Gruyter, 2005.

Leiman, Shnayer Z. The Canonization of Hebrew Scripture: The Talmudic and Midrashic Evidence. Hamden: Archon, 1976.

Levine, Etan B. The Aramaic Version of Qohelet. New York: Sepher-Hermon Press, 1978. 
Longman III, Tremper. The Book of Ecclesiastes. The New International Commentary on the Old Testament. Grand Rapids: Wm. B. Eerdmans Publishing Co., 1998.

Meek, Russell L. "The Meaning of הַָב in Qohelet: An Intertextual Suggestion." Dalam The Words of the Wise Are like Goads: Engaging Qohelet in the 21st Century, disunting oleh Mark J. Boda, Tremper Longman III, dan Cristian G. Rata, 241-256. Winona Lake: Eisenbrauns, 2013.

Ogden, Graham S. Qoheleth. Ed. ke-2. Readings, A New Biblical Commentary. Sheffield: Sheffield Phoenix Press, 2007.

Parsons, Greg W. "Guidelines for Understanding and Proclaiming the Book of Ecclesiastes, Part 1." Bibliotheca Sacra 160 (Juni 2003): 159-173.

Perry, T. A. Dialogues with Kohelet: The Book of Ecclesiastes. University Park: Pennsylvania State University Press, 1993.

- - - The Book of Ecclesiastes (Qohelet) and the Path to Joyous Living. Cambridge: Cambridge University Press, 2015.

Peterson, Jesse M. "Is Coming into Existence Always a Harm? Qoheleth in Dialogue with David Benatar." Harvard Theological Review 112, no. 1 (2019): 33-54. https://doi.org/10.1017/S0017816018000330.

Reitman, James S. “The Structure and Unity of Ecclesiastes.” Bibliotheca Sacra 154 (September 1997): 297-319.

Rindge, Matthew S. "Mortality and Enjoyment: The Interplay of Death and Possessions in Qoheleth." Catholic Biblical Quarterly 73, no. 2 (2011): 265-280.

Sailhamer, John H. Introduction to Old Testament Theology: A Canonical Approach. Grand Rapids: Zondervan, 2010.

Sandberg, Ruth. "Qohelet and the Rabbis." Dalam The Words of the Wise Are like Goads: Engaging Qohelet in the 21st Century, disunting oleh Mark J. Boda, Tremper Longman III, dan Cristian G. Rata, 37-54. Winona Lake: Eisenbrauns, 2013.

Schoors, Anton. The Preacher Sought to Find Pleasing Words: A Study of the Language of Qoheleth. Orientalia Lovaniensia Analecta 41. Leuven: Peeters Press, 1992.

Scott, R. B. Y., ed. Proverbs, Ecclesiastes. Ed. ke-2. The Anchor Bible 18. New York: Doubleday, 1985.

Seow, C. L., ed. Ecclesiastes: A New Translation With Introduction and Commentary. Ed. ke-1. The Anchor Bible 18C. New York: Doubleday, 1997.

Shaw, Benjamin. “On Reading Ecclesiastes.” Dalam The Hope Fulfilled: Essays in Honor of O. Palmer Robertson, disunting oleh Robert L. Penny, 47-58. Phillipsburg: P\&R Publishing Company, 2008.

Shields, Martin A. The End of Wisdom: A Reappraisal of the Historical and Canonical Function of Ecclesiastes. Winona Lake: Eisenbrauns, 2006.

Smith, David L. "The Concept of Death in Job and Ecclesiastes." Didaskalia 4, no. 1 (1992): 2-14.

Sneed, Mark R. The Politics of Pessimism In Ecclesiastes: A Social-Science Approach. Atlanta: Society of Biblical Literature, 2012. 
___. "The Social Location of the Book of Qoheleth." Hebrew Studies 39 (1998): 41-51.

VanGemeren, Willem A., ed. New International Dictionary of Old Testament Theology \& Exegesis. Vol. 3. Grand Rapids: Zondervan, 1997.

-_- ed. New International Dictionary of Old Testament Theology \& Exegesis. Vol. 1. Grand Rapids: Zondervan, 1997.

Von Rad, Gerhard, dan James D. Martin. Wisdom in Israel. London: Xpress Reprints, 1997.

Whitley, Charles F. Koheleth: His Language and Thought. New York: Walter de Gruyter, 1979.

Williams, Neal David. A Biblical Theology of Ecclesiastes. Ann Arbor: University Microfilms International, 1986.

Youngblood, Ronald F. “Qoheleth's 'Dark House' (Eccl. 12:5)." Journal of the Evangelical Theological Society 29, no. 4 (Desember 1986): 397-410.

Zimmermann, Frank. The Inner World of Qohelet. New York: Ktav Pub. House, 1973.

Zuck, Roy B. “God and Man in Ecclesiastes.” Bibliotheca Sacra 148 (Maret 1991): 46-56. 